\title{
Horn bud size of dairy-bred and suckler- bred calves at time of disbudding
}

\author{
Gabriela A. Marquette ${ }^{1,2}$, Mark McGee ${ }^{1}$, Andrew D. Fisher ${ }^{2}$, Kelly Stanger ${ }^{2}$, Anastasio Argüello ${ }^{1}$ and \\ Bernadette Earley ${ }^{1 *}$
}

\begin{abstract}
Background: Hot-iron disbudding is a common management procedure to prevent horn growth in calves. The study objective was to examine effect of age, breed and sex on horn bud size of dairy-bred and suckler-bred calves at time of disbudding.

Results: The left and right horn bud size (diameter and height in $\mathrm{mm}$ ) of 279 calves, including dairy-bred HolsteinFriesian (Male $(M)=88$ ) and 191 suckler-bred (86 Charolais, $C H ;(M=39$, Female $(F)=47), 67$ Limousin, $L M ;(M=32$, $\mathrm{F}=35)$ and 38 Simmental, $\mathrm{Sl} ;(\mathrm{M}=22, \mathrm{~F}=16)$ sired)) was measured using a digital calliper at time of disbudding. Calves were retrospectively assigned to two age categories at time of disbudding: 1), 14 to 28 days (d) old and 2), 29 to $60 \mathrm{~d}$ old. Holstein-Friesian M calves had a greater horn bud diameter (16.97 v.14.45 mm) and height (7.79 v. $5.00 \mathrm{~mm})$ compared to suckler-bred $\mathrm{M}$ calves $(P<0.01)$, with no difference $(P>0.05)$ among the suckler-bred calves. Suckler-bred $M$ calves had a greater horn bud diameter (14.46 vs $13.29 \mathrm{~mm}$ ) and height $(5.01 \mathrm{vs} 3.88 \mathrm{~mm})$ compared to suckler-bred F calves $(P<0.05)$.

The slopes of the lines of best fit show that horn bud diameter and height increased with age $(P<0.05)$ for $\mathrm{HF}$, SI male and $\mathrm{CH}$ female calves while there was no relationship with age $(P>0.05)$ for $\mathrm{CH}$ and $\mathrm{LM}$ male calves, or for $\mathrm{SI}$ and LM female calves. Linear regression of age with diameter and with height for each breed and sex showed high variability in the data as indicated by R-squared values ranging from $0.003-0.41$ indicating that in the case of the diameter and the height, the weight of the fitting effect was poor.

Conclusions: Calf age is not a good predictor of horn bud size and recommendations for the disbudding of calves should be based on horn bud size and not on age. The implications of these findings are that calves should be disbudded while horn development is still at the bud stage and when the bud is large enough to be easily palpable/visible, but not so large that disbudding could lead to severe tissue trauma.
\end{abstract}

Keywords: Calf breed, Age, Sex, Horn bud size, Cautery disbudding

\section{Background}

Disbudding and dehorning are husbandry management procedures, which as a principle are deemed undesirable by society, but permitted in law because there are perceived benefits to human and animal safety. The primary reasons stated for removal of horns or horn buds is to

\footnotetext{
* Correspondence: bernadette.earley@teagasc.ie

${ }^{1}$ Teagasc, Animal \& Grassland Research and Innovation Centre, Grange, Dunsany, Co. Meath C15 PW93, Ireland

Full list of author information is available at the end of the article
}

make the handling of cattle easier and to reduce the risk of injuries (in cattle, other animals and human handlers) associated with horned cattle [1] Disbudding involves the destruction of the cells of the horn bud [2,3] and is defined as the removal of horns in calves up to 2 months (mo) of age [1]. Dehorning refers to the removal of the horn after attachment of the horn bud to the skull, occurring at approximately 2 mo of age [4-6]. Farmers as well as veterinarians, in many countries, consider removal of the horn buds a painful procedure for calves

(c) The Author(s). 2021 Open Access This article is licensed under a Creative Commons Attribution 4.0 International License, which permits use, sharing, adaptation, distribution and reproduction in any medium or format, as long as you give appropriate credit to the original author(s) and the source, provide a link to the Creative Commons licence, and indicate if changes were made. The images or other third party material in this article are included in the article's Creative Commons licence, unless indicated otherwise in a credit line to the material. If material is not included in the article's Creative Commons licence and your intended use is not permitted by statutory regulation or exceeds the permitted use, you will need to obtain permission directly from the copyright holder. To view a copy of this licence, visit http://creativecommons.org/licenses/by/4.0/ The Creative Commons Public Domain Dedication waiver (http://creativecommons.org/publicdomain/zero/1.0/) applies to the data made available in this article, unless otherwise stated in a credit line to the data. 
[7-12]. Disbudding and dehorning procedures are therefore regulated by animal welfare laws. Within the European Union (EU), the disbudding procedure is regulated by European Council Directive 98/58/EC based on the Recommendation Concerning Cattle [13]. In addition, cautery disbudding is recommended by the European Food Safety Authority [14], and is the only method allowed in Ireland under S.I. One hundred twenty-seven of the Animal Health and Welfare [15], which permits disbudding of calves up to 4 weeks of age by thermal cauterisation. Cornual nerve block with local anaesthetic is currently the accepted technique to anaesthetize the horn bud prior to its removal [16].

Under Irish legislation, calves can be disbudded under 2 weeks of age without use of local anaesthesia or analgesia. Administration of a local anaesthetic as a prescription only medicine (POM) by a non-veterinarian stockperson is permitted under Irish legislation for the disbudding of calves from 2 weeks to 4 weeks of age. For calves older than 4 weeks, administration of a local anaesthetic prior to disbudding under veterinary supervision, is mandatory.

A review of the literature indicates that there are differences among countries in the use of hot-iron cautery disbudding. For example, in the Czech Republic, 69.4\% of farmers use the hot-iron cautery disbudding procedure [17], which is similar to the $69.1 \%$ reported in the United States [18] and is lower than that reported in Canada (88.7\% [19]), Brazil (95\% [20];), Italy (90.6\% [6];), France (87\%, [21]), 87.6\% [22]) and EU member states $(80.4 \%$ [1]). In Ireland, the age limits concerning the timing of the disbudding procedure for calves and the administration of local anaesthesia, regardless of breed or sex, are not based on empirical evidence, but rather on farmer opinion related to the physical development of horns [23]. Additionally, there are no recommendations in Ireland as to the provision of pain relief (analgesia) based on age. Research conducted by Dwane et al. [23] using focus groups reported that Irish beef farmers enrolled in the "Suckler Scheme 2008" [24] were reluctant to use local anaesthetic and opted to disbud suckler-bred calves younger than 2 weeks old to avoid using it, even when the horn bud was not palpable. While the 'Disbudding' measure may have been beneficial in reducing the incidence of dehorning of adult cattle [25], early disbudding could result in re-growth and having to repeat the procedure a second time in calves where it was not successful.

Despite the visibility of the horn bud being the characteristic normally adopted by farmers when selecting animals for disbudding, most recommendations are still based on the age of the calf. Research indicates that young calves may be equally or possibly more sensitive to pain than older calves [26], and raises doubts about the validity of age-related anaesthetic and analgesia guidelines. Information is lacking on; 1), the bud size (diameter and height) and age at disbudding and 2), on horn bud size (diameter and height) of contrasting breeds, and of calf sex and if the recommendation to disbud calves based on age is appropriate for all calf breeds.

Therefore, the objective of this study was to examine the effect of age, breed and sex on horn bud size of calves at time of disbudding. Our hypothesis was that the relationship between calf age and horn bud size would differ between breeds, and thus any recommendation for an optimal disbudding age may need to take breed into account, or instead be based on horn bud size itself rather than calf age.

\section{Materials and methods Animals}

A total of 279 calves, including 88 dairy-bred HolsteinFriesian (Male (M)) and 191 suckler-bred (86 Charolais, $\mathrm{CH} ;(\mathrm{M}=39$, Female $(\mathrm{F})=47), 67$ Limousin, LM; $(\mathrm{M}=$ $32, \mathrm{~F}=35)$ and 38 Simmental, SI; $(\mathrm{M}=22, \mathrm{~F}=16))$ sired calves) were used. The Holstein-Friesian $\mathrm{M}$ calves were purchased directly from farms in $2018(n=45)$ and 2019 $(n=43)$ and artificially reared at Teagasc, Grange, Co. Meath. The suckler herd at Teagasc was the source of the suckler bred calves. The cows, Limousin and Simmental crossbred cows were bred to artificial insemination (AI) to Charolais, (CH) Limousin (LI) and Simmental (SI) sires. The M and F suckler-bred calves were spring-born at Teagasc, Grange in $2018(n=88)$ and $2019(n=103)$. The HF calves were the progeny of HF sire with HF dam, there was no Jersey breed influence. All calves were retrospectively assigned to two age categories based on birth dates: (i) 14 to $28 \mathrm{~d}$ (ii), 29 to $60 \mathrm{~d}$.

\section{Local anaesthesia and analgesia}

Each calf was restrained in a disbudding crate. Cornual nerve blockade was administered by a trained farm technician by injecting $2 \mathrm{~mL}$ of local anaesthetic (LA) solution containing Procaine hydrochloride $(50 \mathrm{mg} / \mathrm{mL})$ with adrenaline $(0.2 \mathrm{mg} / \mathrm{mL})$ (Adrenacaine, Norbrook Laboratories Limited, UK). The site of LA injection was located by running a finger along the head from the lateral canthus of the eye to the horn bud on each side of the head. About $3 \mathrm{~cm}$ from the eye along this line, the needle was inserted through the skin under the bony ridge and the anaesthetic deposited. Each HF calf was also administered a subcutaneous injection $0.5 \mathrm{mg} / \mathrm{kg}$ containing 20 $\mathrm{mg} / \mathrm{mL}$ of meloxicam (Metacam $20 \mathrm{mg} / \mathrm{mL}$, Boehringer, Ingelheim, Boehringer, Germany). The suckler bred beef calves were not administered metacam. 


\section{Horn bud measurements}

At the time of disbudding, 20 min after the application of a cornual nerve block using LA and analgesia, calves were moved individually to a disbudding crate and restrained. The hair surrounding each horn bud was clipped using a scissors and the horn bud exposed. The diameter ( $\mathrm{mm}$ ) and height $(\mathrm{mm})$ of the left and right horn buds were measured using a digital calliper (model 49-923-150; Linear Tools, UK) and a clear plastic cylinder (diameter 43 $\mathrm{mm}$; height $30.85 \mathrm{~mm}$ ) which was placed overlying the horn bud prior to disbudding (Fig. 1). The horn bud height was determined using the depth gauge on the calipers as the difference between the depth measured through an aperture in the top of the cylinder to the tip of the horn bud, and the cylinder height. The diameter was determined by placing the outside jaws of the calipers parallel to the horn bud. The same individual carried out all of the horn bud measurements.

Following the horn bud measurements, each calf was disbudded using the farm's standard management practice, using a hot-iron disbudder (model 17,460; KERBL, AgriDirect, Ireland) with a tip diameter of $15 \mathrm{~mm}$. Silver aluminium spray (Henry Schein, Dublin, Ireland) was applied to the

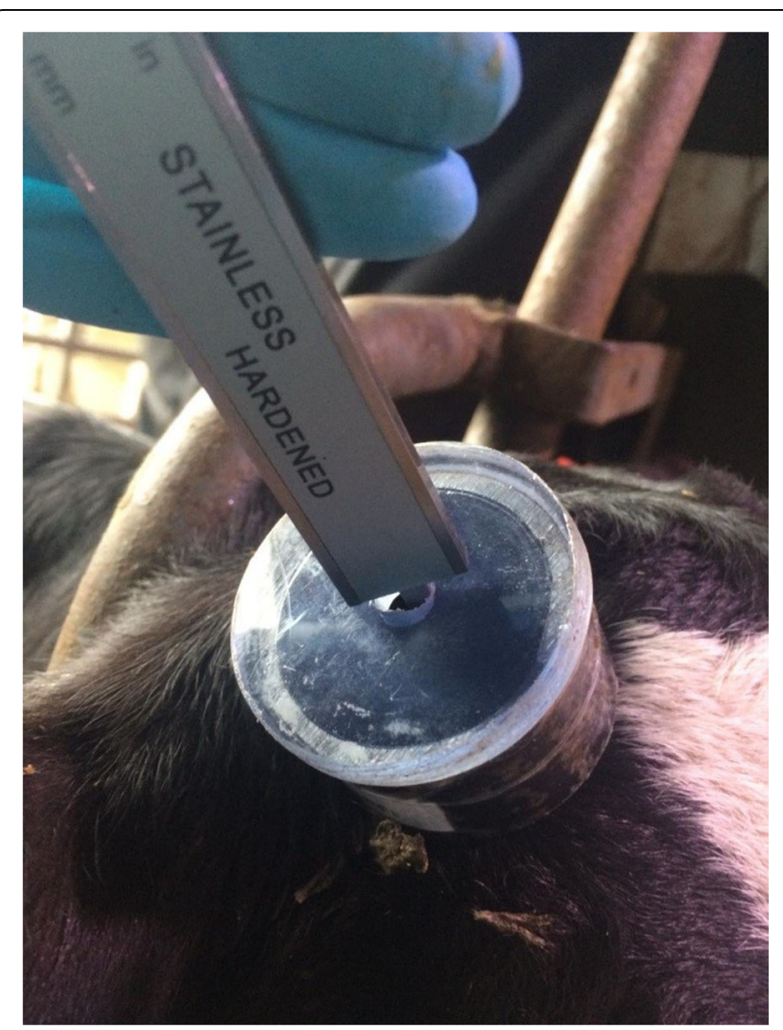

Fig. 1 Methodology used to measure horn bud height showing the depth gauge of the calliper (model 49-923-150; Linear Tools, UK) positioned through the aperture of the cylinder (diameter $43 \mathrm{~mm}$; height $30.85 \mathrm{~mm}$ ) when placed over the horn bud disbudded area following removal of each horn bud and the calves were returned to their home pens.

\section{Statistical analysis}

Statistical analyses were conducted using SAS v.9.4 software [27]. The experimental unit was the animal. A descriptive analysis of the horn bud measurements collected on the right and the left side of each calf was performed in SAS. Since no differences were found between the left and right side horn bud measurements, the mean value for diameters and heights of each calf was used in the subsequent analysis. Data were checked for normality and homogeneity of variance by histograms, q-q plots, and formal statistical tests as part of the UNIVARIATE procedure of SAS. Data that were not normally distributed were transformed by raising the variable to the power of lambda. The appropriate lambda $(\lambda)$ value was obtained by conducting a Box-Cox transformation analysis using the TRANSREG procedure of SAS. Data subjected to transformation were used to calculate $P$-values. Associations between variables and the outcomes of interest were evaluated using mixedeffects linear models (PROC MIX). Horn bud measurements of male dairy-bred and suckler-bred calves were analysed with the fixed effects of year, breed and age included in the model. Bud measurements of suckler beef calves $(\mathrm{CH}, \mathrm{LM}, \mathrm{SI})(n=191)$ were analysed and the fixed effects of sex, age and year included in the model. The corresponding non-transformed least squares means (Lsmeans) with standard error of the mean (SEM) are presented to facilitate interpretation of the results. Differences between the Lsmeans were tested using the PDIFF option in SAS or Tukey where appropriate. Lsmeans were considered significantly different at a probability level of $P<0.05$. Simple linear regression analysis (PROC REG) was used to estimate the equation of the line that best described the association between age with bud size (diameter and height) for each breed and for sex within breed. The regression coefficients and coefficient of determination ( $\mathrm{R}$ square) were calculated. The PROC CORR procedure Spearman rank correlation $\left(r_{\mathrm{sp}}\right)$ was used to describe the correlation matrix on the variables, diameter $(\mathrm{mm})$ with height $(\mathrm{mm})$ data for each breed and for sex within breed. Multivariable linear regression (PROC GLM MANOVA in SAS 9.4) was used to compare the slopes generated from the linear regression analyses.

\section{Results}

\section{Age at disbudding}

In the present study, $16 \%$ of HF males calves were disbudded between 14 and $28 \mathrm{~d}$ and the remaining $84 \%$ between 29 and $60 \mathrm{~d}$ with $50 \%$ of suckler-bred calves disbudded at either $14-28 \mathrm{~d}$ or $29-60 \mathrm{~d}$ old. The mean 
(SD) age of HF male calves at disbudding was 37 [10] days while the corresponding ages for the suckler-bred female and male calves was 26 [8] (CH), 28 [9] (LM), 23 [6] (SI) d, and 24 [7] (CH), 26 [7] (LM) and 23 [6] (SI) d, respectively.

\section{Effect of breed and age on horn bud diameter and height} of dairy-bred and suckler-bred male calves

There was no breed $\times$ age interaction $(P>0.05)$ for horn bud diameter or height. There was an effect of breed and of age on horn bud diameter $(P<0.0075, P<0.017$, respectively) and height $(P<0.0086, P<0.0073$, respectively) (Table 1$)$. HF calves had a greater $(P<0.01)$ horn bud diameter and height compared to suckler-bred calves, with no difference $(P>0.05)$ among $\mathrm{CH}$, LM or SI sired suckler breeds. Horn bud diameter and height was greater $(P<0.05)$ in calves disbudded at $28-60 \mathrm{~d}$ compared to $14-28 \mathrm{~d}$ old calves. There was no year $\times$ age interaction $(P>0.05)$ and an effect of year where horn bud diameter was greater $(P<0.05)$ in 2019 compared to 2018 with no difference $(P>0.05)$ in height.

\section{Effect of breed and sex on horn bud diameter and height of suckler-bred calves}

There was no sex $x$ age interaction or breed $x$ age interaction for horn bud measurements of suckler-bred beef calves (Table 2). There was an effect of sex and age on horn bud diameter and height with suckler-bred $M$ beef calves having greater $(P<0.01)$ horn bud diameter and height than suckler-bred $\mathrm{F}$ calves (Table 2). Horn bud diameter and height was greater $(P<0.05)$ on sucklerbred calves disbudded at 28-60 d old compared to 14$28 \mathrm{~d}$ calves.

The slopes of the lines of best fit show that horn bud diameter and height increased with age $(P<0.05)$ for $\mathrm{HF}$, SI male and $\mathrm{CH}$ female calves while there was no relationship with age for $\mathrm{CH}$ and LM male calves, or for SI and LM female calves $(P>0.05)$. Linear regression of age with diameter and with height for each breed and sex are shown in Table 3 . The variability in the data was high as indicated by $\mathrm{R}$-squared values (Table 3 ). The values ranged from $0.003-0.41$ indicating that in the case of the diameter and the height, the weight of the fitting effect was poor. The horn bud growth (slope) of dairy-bred male calves was $0.20 \mathrm{~mm} /$ day for diameter and $0.22 \mathrm{~mm} /$ day for height while the growth (slope) of suckler-bred beef calves was less than $0.1 \mathrm{~mm} /$ day.

The correlation coefficients between diameter with height measurements were correlated for all breeds $(P<0.05)$ and for sex $(P<0.05)$ within breed (Table 4$)$.

Multivariable linear regression models (GLIMMIX procedure) was used to compare age with horn bud measurements for $\mathrm{HF}$ and suckler-bred $(\mathrm{CH}, \mathrm{LM}, \mathrm{SM})$ male calves (Table 5). The diameter and height was 3.54 $\mathrm{mm}$ and $3.00 \mathrm{~mm}$, respectively, greater than the intercepts $(15.87 \mathrm{~mm}, 6.18 \mathrm{~mm}$ respectively) for HF male calves compared with the suckler-bred beef calves while there was no difference among the suckler-bred $M$ calves. Calves disbudded at 29-60 d had greater horn bud diameter (increase of $1.31 \mathrm{~mm}$ ) and height (increase of $1.84 \mathrm{~mm}$ ) than calves disbudded at 14-28 d old $(P<0.01)$ (Table 5).

Multivariable linear regression models (GLIMMIX procedure) was used to compare the regression lines for effect of suckler breed (CH, LM, SM), sex and age (Table 6) on horn bud size. The diameter and height for the suckler-bred $\mathrm{CH}$, LM, SM was not different from the intercepts for diameter $(15.09 \mathrm{~mm})$ and height $(4.71 \mathrm{~mm})$. There was a sex effect for diameter and height where male calves had a diameter of $1.33 \mathrm{~mm}$ and a height of $1.01 \mathrm{~mm}$ greater than the corresponding intercepts $(15.09 \mathrm{~mm}, 4.71 \mathrm{~mm}$, respectively) when compared to suckler-bred F calves. Calves disbudded at 29$60 \mathrm{~d}$ had greater horn bud diameter (increase of $1.32 \mathrm{~mm}$ ) $(P<0.05)$ and height (increase of $0.64 \mathrm{~mm})(P<0.05)$ than calves disbudded at 14-28 d old.

\section{Discussion}

To the best of our knowledge, this is the first study that has quantified horn bud size of dairy-bred and sucklerbred calves at time of disbudding. In the present study, the dairy-bred calves were purchased after $28 \mathrm{~d}$ old directly from farms and assembled at Teagasc Grange. The dairy-bred calves were disbudded within 1 week after

Table 1 Effect of breed, age and year on horn bud diameter and height of male dairy-bred and suckler-bred calves at disbudding $(n=181)$

\begin{tabular}{|c|c|c|c|c|c|c|c|c|c|c|c|c|c|c|c|c|c|}
\hline Variable & $\mathrm{HF}$ & $\mathrm{CH}$ & LIM & SI & SE & $14-28 d$ & $29-60 d$ & SE & 2018 & 2019 & SE & Breed & Age & Year & $\begin{array}{l}\text { Breed } \\
\times \text { age }\end{array}$ & $\begin{array}{l}\text { Year } \\
\times \text { age }\end{array}$ & $\begin{array}{l}\text { Year } \times \text { Breed } \\
\times \text { Age }\end{array}$ \\
\hline $\begin{array}{l}\text { Diameter } \\
(\mathrm{mm})\end{array}$ & $16.97^{a}$ & $15.09^{b}$ & $13.76^{b}$ & $14.41^{b}$ & 0.62 & 14.31 & $15.81^{b}$ & 0.44 & 14.31 & $15.80^{*}$ & 0.44 & $* *$ & * & * & NS & NS & NS \\
\hline $\begin{array}{l}\text { Height } \\
\text { (mm) }\end{array}$ & $7.79^{a}$ & $5.10^{b}$ & $4.69^{b}$ & $5.39^{b}$ & 0.62 & 4.88 & $6.60^{b}$ & 0.44 & 5.91 & 5.57 & 0.44 & ** & $* *$ & NS & NS & NS & NS \\
\hline
\end{tabular}

a,b Within rows, Lsmeans differ between breed, age categories and year $(P<0.05)$

$H F$ Holstein-Friesian, $C H$ Charolais, LM Limousin, SI Simmental

$d$ days old at disbudding, NS not significant $(P>0.05) .{ }^{*} P<0.05,{ }^{* *} P<0.01$

SEM pooled standard error 
Table 2 Effect of sex, age and year on horn bud diameter $(\mathrm{mm})$ and height $(\mathrm{mm})$ of suckler-bred male and female calves at disbudding $(n=191)$

\begin{tabular}{|c|c|c|c|c|c|c|c|c|c|c|c|c|c|c|c|}
\hline \multirow[b]{2}{*}{ Variable } & \multirow[b]{2}{*}{ Female } & \multirow[b]{2}{*}{ Male } & \multirow[b]{2}{*}{ SE } & \multirow[b]{2}{*}{$14-28 d$} & \multirow[b]{2}{*}{$29-60 \mathrm{~d}$} & \multirow[b]{2}{*}{ SE } & \multirow[b]{2}{*}{2018} & \multirow[b]{2}{*}{2019} & \multirow[b]{2}{*}{ SE } & \multicolumn{6}{|c|}{$P$ Value } \\
\hline & & & & & & & & & & Sex & Age & Year & $\begin{array}{l}\text { Sex } \times \\
\text { Age }\end{array}$ & $\begin{array}{l}\text { Sex } \\
\times \text { Year }\end{array}$ & $\begin{array}{l}\text { Year } \\
\times \text { Age }\end{array}$ \\
\hline Diameter (mm) & $13.29^{a}$ & $14.46^{b}$ & 0.278 & 13.16 & $14.58^{b}$ & 0.274 & $13.37^{a}$ & $14.38^{b}$ & 0.278 & $* *$ & ** & * & NS & NS & NS \\
\hline Height (mm) & $3.88^{a}$ & $5.01^{b}$ & 0.214 & 4.11 & $4.78^{b}$ & 0.201 & $4.88^{a}$ & $4.01^{b}$ & 0.214 & $* *$ & * & $* *$ & NS & NS & NS \\
\hline
\end{tabular}

a,b Within rows, Lsmeans differ between year, sex and age categories $(P<0.05)$

$d$ days old at disbudding, NS not significant $(P>0.05)$. ${ }^{*} P<0.05$, ${ }^{* *} P<0.01$

SE pooled standard error

arrival and a greater number were disbudded at an older age in 2019.

There is limited information in the literature on age at cautery disbudding for suckler-bred beef calves with most studies reporting on cautery disbudding of dairy-bred calves. For example, the mean disbudding age in the present study was greater than that reported by Stanek et al. [17] (median 20 d; 2.9 week) for dairy calves on Czech farms, but lower than 6.4 weeks (median) in Canada [15] and 4.6 weeks (mean) in Italy [6]. The age range at disbudding reported by Stanek et al. [17] on surveyed Czech farms ranged from 3 to $68 \mathrm{~d}$ of age. A possible reason why calves were disbudded before $28 \mathrm{~d}$ of age on Czech farms is that legislation allows the disbudding of calves without the use of pain relief up to $28 \mathrm{~d}$. In the Stanek et al. [17] study, $63.3 \%$ of calves were disbudded before $28 \mathrm{~d}$ of age, which is greater than those reported in other studies: $21 \%$ in Canada [28], $25.7 \%$ in the US
[29] and 17\% in southern Brazil [20] and lower than those reported (95\%) in Finland [30].

In the present study, horn bud diameter and height were very variable across breeds which suggest that most of the variation is not explained by age. It is possible that some of the variation, at least for the suckler-bred calves, may be attributed to calf sex since male suckler-bred calves had a greater horn bud height $(29.1 \%)$ and diameter $(8.80 \%)$ compared with female suckler calves at time of disbudding. However, this finding is unsurprising for male calves as there is general agreement that the main evolutionary benefit of males having larger horns than females relates to intra-sexual competition for mates [7, $31,32]$. In the present study, while no dairy-bred females were included in the study, it would be of interest to quantify the horn bud measurements of male and female dairy-bred calves at time of disbudding.

A number of studies have focused on the acute pain response to cautery disbudding [33-36] and of the

Table 3 Linear regression analysis describing the line of best fit for the relationship between age with diameter ( $\mathrm{mm}$ ), and age with height $(\mathrm{mm})$ for dairy-bred $M$ calves and suckler-bred $M$ and $F$ calves at disbudding (showing $R$ square and level of significance ( $P$ value))

\begin{tabular}{|c|c|c|c|c|c|}
\hline Variable (mm) & Breed and number & Sex & Linear regression & $\mathrm{R}$ square & $P$-value \\
\hline Diameter & $\mathrm{HF}(\mathrm{n}=88)$ & M & $y=0.2044 x+10.2470$ & 0.320 & $<0.0001$ \\
\hline Height & $\mathrm{HF}(n=88)$ & M & $y=0.2249 x+0.2481$ & 0.410 & $<0.0001$ \\
\hline Diameter & $\operatorname{LM}(n=32)$ & M & $y=0.0374 x+12.990$ & 0.093 & 0.0903 \\
\hline Height & $\operatorname{LM}(n=32)$ & M & $y=0.0512 x+3.679$ & 0.073 & 0.1343 \\
\hline Diameter & $\operatorname{LM}(n=35)$ & $\mathrm{F}$ & $y=0.0742 x+10.613$ & 0.091 & 0.0786 \\
\hline Height & $\operatorname{LM}(n=35)$ & $\mathrm{F}$ & $y=-0.0512 x+3.679$ & 0.073 & 0.1343 \\
\hline Diameter & $\mathrm{CH}(n=39)$ & M & $y=0.0507 x+13.932$ & 0.073 & 0.0872 \\
\hline Height & $\mathrm{CH}(\mathrm{n}=39)$ & M & $y=0.0507 x+13.932$ & 0.073 & 0.0872 \\
\hline Diameter & $\mathrm{CH}(n=47)$ & $\mathrm{F}$ & $y=0.0752 x+11.73$ & 0.175 & 0.0031 \\
\hline Height & $\mathrm{CH}(\mathrm{n}=47)$ & $\mathrm{F}$ & $y=0.0049 x+3.5037$ & 0.003 & 0.7209 \\
\hline Diameter & $\mathrm{SI}(n=22)$ & M & $y=0.0606 x+13.02$ & 0.279 & 0.0097 \\
\hline Height & SI $(n=22)$ & M & $y=0.0606 x+13.02$ & 0.279 & 0.0097 \\
\hline Diameter & $\mathrm{SI}(n=16)$ & $\mathrm{F}$ & $y=-0.00091 x+12.392$ & 0.088 & 0.2482 \\
\hline Height & SI $(n=16)$ & $\mathrm{F}$ & $y=-0.0413 x+3.8698$ & 0.036 & 0.4672 \\
\hline
\end{tabular}

HF Holstein-Friesian, $\mathrm{CH}$ Charolais, LM Limousin, SI Simmental 
Table 4 Correlation matrix of diameter with height for dairy-bred and suckler-bred $M$ and $F$ calves at disbudding, coefficient of determination (R square) and level of significance ( $P$-value)

\begin{tabular}{|c|c|c|c|c|c|}
\hline Variable (mm) & Breed and number & Sex & Intercept & R square & $P$ value \\
\hline Diameter & $\mathrm{HF}(\mathrm{n}=88)$ & M & -3.5055 & 0.483 & $<0.0001$ \\
\hline Height & $\mathrm{HF}(\mathrm{n}=88)$ & M & & & \\
\hline Diameter & $\operatorname{LM}(n=32)$ & M & -4.541 & 0.593 & $<0.0001$ \\
\hline Height & $\operatorname{LM}(n=32)$ & M & & & \\
\hline Diameter & $\operatorname{LM}(n=35)$ & $\mathrm{F}$ & -2.7102 & 0.446 & $<0.0001$ \\
\hline Height & $\operatorname{LM}(n=35)$ & $\mathrm{F}$ & & & \\
\hline Diameter & $\mathrm{CH}(\mathrm{n}=39)$ & M & 9.79865 & 0.652 & $<0.0001$ \\
\hline Height & $\mathrm{CH}(\mathrm{n}=39)$ & M & & & \\
\hline Diameter & $\mathrm{CH}(\mathrm{n}=47)$ & $\mathrm{F}$ & -0.68857 & 0.268 & 0.0002 \\
\hline Height & $\mathrm{CH}(\mathrm{n}=47)$ & $\mathrm{F}$ & & & \\
\hline Diameter & $\mathrm{SI}(\mathrm{n}=22)$ & M & -2.7102 & 0.446 & $<0.0001$ \\
\hline Height & $\mathrm{SI}(\mathrm{n}=22)$ & M & & & \\
\hline Diameter & $\mathrm{SI}(\mathrm{n}=16)$ & $\mathrm{F}$ & -3.1919 & 0.550 & 0.0007 \\
\hline Height & $S I(n=16)$ & $\mathrm{F}$ & & & \\
\hline
\end{tabular}

HF Holstein-Friesian, $\mathrm{CH}$ Charolais, $L M$ Limousin, $S /$ Simmental. $d$ days old at disbudding. $M$ male. $F$ female. Correlation (effect size and the strength of the correlation) was described using the following: 0.00-0.19 "very weak"; $0.20-0.39$ "weak"; 0.40-0.59 "moderate"; 0.60-0.79 "strong"; 0.80-1.0 "very strong"

Table 5 Multivariable linear regression of breed, age and year on horn bud diameter and height of dairy-bred and sucklerbred male calves at disbudding $(n=181)$

\begin{tabular}{|c|c|c|c|c|c|c|}
\hline & Estimate & SE & $P$ value & Breed & Age & Year \\
\hline \multicolumn{7}{|c|}{ Horn bud diameter } \\
\hline Intercept & 15.87 & 0.715 & $<.0001$ & $<.0001$ & 0.011 & $<.0001$ \\
\hline HF & 3.54 & 0.733 & $<.0001$ & & & \\
\hline $\mathrm{CH}$ & 1.05 & 0.750 & 0.1617 & & & \\
\hline LM & 0.07 & 0.784 & 0.9243 & & & \\
\hline SI & $0.00^{\mathrm{a}}$ & . & . & & & \\
\hline Age $14-28 d$ & $0.00^{b}$ & . & & & & \\
\hline Age $29-60 d$ & 1.31 & 0.509 & 0.011 & & & \\
\hline 2018 & $0.00^{c}$ & . & & & & \\
\hline 2019 & 2.49 & 0.427 & $<.0001$ & & & \\
\hline \multicolumn{7}{|c|}{ Horn bud height } \\
\hline Intercept & 6.18 & 0.709 & $<.0001$ & $<.0001$ & 0.0003 & 0.4509 \\
\hline $\mathrm{HF}$ & 3.00 & 0.727 & $<.0001$ & & & \\
\hline $\mathrm{CH}$ & 0.25 & 0.743 & 0.7336 & & & \\
\hline LM & 0.13 & 0.777 & 0.8689 & & & \\
\hline SI & $0.00^{\mathrm{a}}$ & . & . & & & \\
\hline Age $14-28 d$ & $0.00^{b}$ & . & . & & & \\
\hline Age $29-60 d$ & 1.84 & 0.504 & 0.0003 & & & \\
\hline 2018 & $0.00^{c}$ & . & . & & & \\
\hline 2019 & 0.32 & 0.424 & 0.4509 & & & \\
\hline
\end{tabular}

HF Holstein-Friesian, CH Charolais, LM Limousin, SI Simmental $d$ days old at disbudding. ${ }^{\text {a }}$ Referent for breed. ${ }^{\text {b }}$ Referent for age. ${ }^{\mathrm{c}}$ Referent for year benefits of providing local anaesthesia and pain relief $[12,37-41]$ at the time of disbudding. Adcock and Tucker [36] reported that calves disbudded at $3 \mathrm{~d}$ versus $35 \mathrm{~d}$ of age were more sensitive to pain after disbudding. Similar findings of increased sensitivity are reported by Casoni et al. [42] for up to 14 weeks post-disbudding of $7 \mathrm{~d}$ and $28 \mathrm{~d}$ old Holstein calves. However, while local anaesthesia in addition to analgesia are of benefit in mitigating the pain related disbudding behaviours, few studies have investigated the responses of contrasting breeds, sex and age of calves on recommendations for age-related anaesthetic and analgesic protocols. Caray et al. [43] reported some effects of age, breed or sex on the behavior of calves that were observed between 2 and $7 \mathrm{~h}$ after disbudding (for example 4-week calves and Charolais calves were more active than their 1-week and Holstein counterparts), but found no interactions between age, breed, sex and treatment medication.

The degree of tissue damage associated with disbudding is reported to be influenced by the stage of development of the horn bud (36). For example, in younger calves the burning of the vessels surrounding the horn bud is sufficient, whereas the whole bud needs to be removed (by levering it out from the side) when the horn is further developed [36]. Therefore, depending on the procedure, calves with greater horn bud diameter at time of disbudding may have more tissue damage which could lead to prolonged healing time and prolonged stress. Disbudding of smaller horn buds may be preferential since less tissue is damaged and it could decrease wound healing time. 
Table 6 Multivariable linear regression of age, sex and year on horn bud diameter and height of suckler-bred male and female calves at disbudding $(n=191)$

\begin{tabular}{|c|c|c|c|c|c|c|c|}
\hline & Estimate & SE & $P$ value & Breed & Sex & Age & Year \\
\hline \multicolumn{8}{|c|}{ Horn bud diameter } \\
\hline Intercept & 15.09 & 0.563 & $<.0001$ & 0.0576 & 0.0003 & 0.0009 & 0.0823 \\
\hline $\mathrm{CH}$ & 0.96 & 0.493 & 0.0533 & & & & \\
\hline LM & 0.05 & 0.515 & 0.9155 & & & & \\
\hline SIM & $0.00^{\mathrm{a}}$ & . & . & & & & \\
\hline Female & $0.00^{b}$ & . & . & & & & \\
\hline Male & 1.33 & 0.360 & 0.0003 & & & & \\
\hline Age $14-28 d$ & $0.00^{c}$ & & . & & & & \\
\hline Age $29-60 \mathrm{~d}$ & 1.32 & 0.391 & 0.0009 & & & & \\
\hline 2018 & $0.00^{d}$ & . & . & & & & \\
\hline 2019 & 0.68 & 0.389 & 0.0823 & & & & \\
\hline \multicolumn{8}{|c|}{ Horn bud height } \\
\hline Intercept & 4.71 & 0.443 & $<.0001$ & 0.719 & 0.0004 & 0.0536 & 0.0055 \\
\hline $\mathrm{CH}$ & 0.24 & 0.388 & 0.5358 & & & & \\
\hline LM & 0.01 & 0.405 & 0.9818 & & & & \\
\hline SIM & $0.00^{\mathrm{a}}$ & . & . & & & & \\
\hline Female & $0.00^{b}$ & . & . & & & & \\
\hline Male & 1.01 & 0.284 & 0.0004 & & & & \\
\hline Age $14-28 d$ & $0.00^{c}$ & . & . & & & & \\
\hline Age 29-60 d & 0.60 & 0.308 & 0.0536 & & & & \\
\hline 2018 & $0.00^{\mathrm{d}}$ & . & & & & & \\
\hline 2019 & 0.86 & 0.306 & 0.0055 & & & & \\
\hline
\end{tabular}

CH Charolais, LM Limousin, SI Simmental

$d$ days old at disbudding. ${ }^{a}$ Referent for breed. ${ }^{b}$ Referent for sex. ${ }^{c}$ Referent for age. ${ }^{d}$ Referent for year.

In the present study, the horn bud size (diameter and height) was greater for dairy-bred than suckler-bred male calves at time of disbudding, and male suckler-bred calves had greater diameters and heights compared to suckler-bred female calves. Additionally, the disbudding of calves with an appropriate disbudder tip size is a consideration and may be a more practical strategy for mitigating pain and improving wound healing. Empirical evidence is lacking on the stress response and wound healing time of calves, when horn buds of varying size are removed using an appropriate disbudder tip diameter. At the time of disbudding, the horn bud should be large enough to be visible/palpable, but not so large that the disbudding device doesn't work or that the trauma is greater. Similarly, the calf should be old enough to have a horn bud but not so old that their horns are too large as this would greatly increase trauma and prolong wound healing time.

\section{Conclusions}

Setting definite ages for disbudding is difficult. The horn bud size (diameter and height) was greater in dairy-bred calves than suckler-bred beef calves at time of disbudding, and male suckler-bred calves had greater horn bud size than female counterparts. This information would be useful to guide more specific recommendations on calf disbudding. The association between age and horn bud size was very weak in dairy-bred and suckler-bred calves. Further work needs to investigate effect of disbudding horn buds of different size on pain responses, behaviour, horn re-growth, and postdisbudding trauma/infections in particular types or breeds of cattle before a more concrete recommendation can be made.

\section{Abbreviations}

M: Male; F: Female; d: day; mo: month; HF: Holstein-Friesian; CH: Charolais; LM: Limousin; SI: Simmental

\section{Acknowledgements}

The authors would like to extend their thanks to: the field research Technicians (Eddie Mulligan and John Horan) and the farm Staff for the care and management of the animals at Teagasc AGRIC Grange.

$\mathrm{BE}, \mathrm{MMCG}, \mathrm{ADF}$ designed the study. GM and $\mathrm{AH}$ collected the horn bud measurements. BE, MMcG, ADF and KS advised on data analysis. BE, GM analysed the data. $B E, M M c G, G M, A D F, K S$ helped to prepare the manuscript. All authors read and approved the final manuscript. 


\section{Funding}

Gabriela Marquette was in receipt of a Teagasc post-graduate Walsh Scholarship.

\section{Availability of data and materials}

All data supporting these research findings are included within the manuscript. The databases (without personally identifiable information) are available from the corresponding author upon request.

\section{Declarations}

\section{Ethics approval}

Project and individual authorisations, in accordance with European Union (Protection of Animals used for Scientific Purposes) Regulations 2012 (S.I. No. 543 of 2012) as amended and Directive 2010/63/EU, were obtained (Health Products Regulatory Authority, Dublin, Ireland (AE19132-P068)). All study procedures were also reviewed and approved by the Teagasc Animal Ethics Committee (TAEC-147- 2017).

\section{Consent for publication}

Not applicable.

\section{Competing interests}

The authors declare that they have no competing interests.

\section{Author details}

'Teagasc, Animal \& Grassland Research and Innovation Centre, Grange, Dunsany, Co. Meath C15 PW93, Ireland. ${ }^{2}$ Faculty of Veterinary and Agricultural Sciences, University of Melbourne, Melbourne, Australia.

Received: 11 March 2021 Accepted: 3 June 2021

Published online: 16 June 2021

\section{References}

1. Cozzi G, Gottardo F, Brscic M, Contiero B, Irrgang N, Knierim U, et al. Dehorning of cattle in the EU member states: a quantitative survey of the current practices. Livest Sci. 2015:179:4-11.

2. ALCASDE. 2009. Appendix 20: Report on dehorning practices across EU member states. Available from: http://www.vuzv.sk/DB-Welfare/telata/ca Ives_alcasde_D-2-2-1.pdf

3. American Veterinary Medical Association (AVMA), 2018 American Veterinary Medical Association Castration and dehorning of cattle https://www.avma. org/KB/Policies/Pages/Castration-and-Dehorning-of-Cattle.aspx (2018), Accessed 20 Apr 2020

4. La Fontaine D. Dehorning and castration of calves under six months of age. Available at: La Fontaine. D. 2007. Dehorning and castration of calves under six months of age. Available at: https://fdocuments.in/reader/full/welfareimplications-of-the-dehorning-and-disbudding-of-cattlethehillcomima gesstorieswhitepaperspdfavmadehorningcattlepdf Accessed 11 Mar 2021.

5. Canadian Veterinary Medical Association (CVMA), 2010. Disbudding and dehorning of cattle-Position statement. Accessed 20 July 2020. http://www. canadianveterinarians.net/documents/disbudding-and-dehorning-of-cattle.

6. Gottardo F, Nalon E, Contiero B, Normando S, Dalvit P, Cozzi G. The dehorning of dairy calves: practices and opinions of 639 farmers. J Dairy Sci. 2011:94:5724-34.

7. Knierim U, Irrgang N, Roth BA. To be or not to be horned - consequences in cattle. Livest Sci. 2015;179:29-37.

8. Huxley JN, Whay HR. Current attitudes of cattle practitioners to pain and the use of analgesics in cattle. Vet Rec. 2006;159:662-8.

9. Hewson CJ, Dohoo IR, Lemke KA, Barkema HW. Canadian veterinarians' use of analgesics in cattle, pigs, and horses in 2004 and 2005. Can Vet J. 2007; 48:155-64.

10. Fajt VR, Wagner SA, Norby B. Analgesic drug administration and attitudes about analgesia in cattle among bovine practitioners in the united sates. $J$ Am Vet Med Assoc. 2011;238:755-67.

11. Wikman I, Hokkanen AH, Pastell M, Kauppinen T, Valros A, Hänninen L. Attitudes of beef producers to disbudding and perception of pain in cattle. Anim Welf. 2016;25:429-38.

12. Stock ML, Baldridge SL, Griffin D, Coetzee JF. Bovine dehorning: assessing pain and providing analgesic management. Vet Clin North Am Food Anim Pract. 2013;29:103-33.
13. European Union 1988 - Council of Europe Standing Committee, (EU 1988), Recommendation concerning cattle adopted by the Standing Committee on 21 October 1988. Accessed 11 Mar 2021.

14. EFSA. 2012. Scientific Opinion on the welfare of cattle kept for beef production and the welfare in intensive calf farming systems. Available from: http://doi.wiley.com/10.2903/j.efsa.2012.2669

15. Animal Health and Welfare (AHAW) 2013. Available from: http://www. irishstatutebook.ie/eli/2013/act/15/enacted/en/html S.I. No. 107 of. 2014 Animal Health and Welfare (Section 17) Regulations 2014. Available from: http://www.irishstatutebook.ie/eli/2014/si/107/made/en/pdf. S.I. No. 127 of. 2014. Animal Health and Welfare (Operations and Procedures) (No. 2) Regulations 2014. Available from: http://www.irishstatutebook.ie/eli/2014/si/ 127/made/en/pdf

16. Fierheller EE, Caulkett NA, Haley DB, Florence D. DoepeL. Onset, duration and efficacy of four methods of local anesthesia of the horn bud in calves. Vet. Anaesth Analg. 2012;39(4):431-5.

17. Stanek S, Šárová R, Nejedlá E, Šlosárková S, Doležal O. Survey of disbudding practice on Czech dairy farms. J Dairy Sci. 2018;101:830-9 https://doi.org/1 0.3168/jds.2017-13143.

18. USDA, 2008. Dairy 2007, Part IV: Reference of Dairy Cattle Health and Management Practices in the United States, 2007. Accessed 21 July 2020. https://www.aphis.usda.gov/animalhealth/nahms/dairy/downloads/dairy07/ Dairy07/dr PartIV.pdf.

19. Vasseur E, Borderas F, Cue RI, Lefebvre D, Pellerin D, Rushen J, et al. A survey of dairy calf management practices in Canada that affect animal welfare. J Dairy Sci. 2010;93:1307-16.

20. Hötzel MJ, Longo C, Balcao LF, Cardoso CS, Costa JHC. A survey of management practices that influence performance and welfare of dairy calves reared in southern Brazil. PLoS One. 2014;9:e114995.

21. Le Cozler Y, Recourse O, Ganche E, Giraud D, Daniel J, Bertin M, et al. A survey on dairy heifer farm management practices in a Western-European plainland, the French pays de la Loire region. J Agric Sci. 2012;150:518-33.

22. de Boyer des Roches A, Veissier I, Coignard M, Bareille N, Guatteo R, Capdeville J, Gilot-Fromont E, Mounier L. The major welfare problems of dairy cows in French commercial farms: an epidemiological approach. Anim. Welf. 2014; 23:467-78.

23. Dwane AM, More SJ, Blake M, McKenzie K, Hanlon AJ. Farmers' self-reported perceptions and behavioural impacts of a welfare scheme for suckler beef cattle in Ireland. Ir Vet J. 2013;66:1-11.

24. DAFM (2008) Department of Agriculture, Food and the Marine: Terms and Conditions Animal Welfare, Recording and Breeding Scheme for Suckler Herds, Ireland.; https://www.agriculture.gov.ie/media/migration/publica tions/2012/SucklerVFMReview310112.pdf

25. DAFM (2011) Department of Agriculture, Food and the Marine: Ireland. Value for money review Animal Welfare, Recording and Breeding Scheme for Suckler Herds -December 2011. 2011, Available at: http://www.agriculture.gov.ie/ media/migration/publications/2012/SucklerVFMReview310112.pdf

26. Soulsby L, Morton DB (Eds): FRAME/RSM conference on: Pain: Nature and management in man and animals: 30/31 March 2000; London, UK; 2001. See chapter by Maria Fitzgerald.

27. SAS. 2003. Version 9.4, SAS Institute Inc., Cary, NC, USA.

28. Misch LJ, Duffield TF, Millman ST, Lissemore KD. An investigation into the practices of dairy producers and veterinarians in dehorning dairy calves in Ontario. Can Vet J. 2007:48:1249-54.

29. Fulwider WK, Grandin T, Rollin BE, Engle TE, Dalsted NL, Lamm WD. Survey of dairy management practices on one hundred thirteen north central and northeastern United States dairies. J Dairy Sci. 2008:91:1686-92.

30. Hokkanen AH, Wikman I, Korhonen T, Pastell M, Valros A, Vainio O, et al. Perceptions and practices of Finnish dairy producers on disbudding pain in calves. J Dairy Sci. 2015:98:823-31.

31. Preston BT, Stevenson IR, Pemberton JM, Coltman DW, Wilson K. Overt and covert competition in a promiscuous mammal: the importance of weaponry and testes size to male reproductive success. Proc R Soc Lond. 2003:B270:633-40.

32. Bro-Jørgensen J. 2007. The intensity of sexual selection predicts weapon size in male bovids. Evolution. 2007:61:1316-26.

33. Winder CB, LeBlanc SJ, Haley DB, Lissemore KD, Godkin MA, Duffield TF. Practices for the disbudding and dehorning of dairy calves by veterinarians and dairy producers in Ontario, Canada. J Dairy Sci. 2016;99:10161-73.

34. Winder CB, Miltenburg CL, Sargeant JM, LeBlanc SJ, Haley B, Lissemore KD, et al. Effects of local anesthetic or systemic analgesia on pain associated 
with cautery disbudding in calves: a systematic review and meta-analysis. J Dairy Sci. 2018;101(6):5411-27.

35. Herskin MS, Nielsen BH. Welfare effects of the use of a combination of local anesthesia and NSAID for disbudding analgesia in dairy calves-reviewed across different welfare concerns. Front Vet Sci. 2018;5:1-16.

36. Adcock SJJ, Tucker CB. The effect of disbudding age on healing and pain sensitivity in dairy calves. J Dairy Sci. 2018;101:10361-73.

37. Stock ML, Barth LA, van Engen NK, Millman ST, Gehring R, Wang C, et al. Impact of carprofen administration on stress and nociception responses of calves to cautery dehorning. J Anim Sci. 2016;94:542-55.

38. Allen KA, Coetzee JF, Edwards-Callaway LN, Glynn H, Dockweiler J, KuKanich $B$, et al. The effect of timing of oral meloxicam administration on physiological responses in calves after cautery dehorning with local anesthesia. J Dairy Sci. 2013;96:5194-05.

39. Bates A, Eder P, Laven R. Effect of analgesia and anti-inflammatory treatment on weight gain and milk intake of dairy calves after disbudding. N Z Vet J. 2015;63:153-7.

40. Bates AJ, Laven R, Chapple F, Weeks D. The effect of different combinations of local anaesthesia, sedative and nonsteroidal anti-inflammatory drugs on daily growth rates of dairy calves after disbudding. N Z Vet J. 2016;64:282-7. https://doi.org/10.1080/00480169.2016.1196626.

41. Bates AJ, Sutherland MA, Chapple F, Dowling SK, Johnson AP, Saldias B, et al. A new method of administering local anesthesia for calf disbudding: findings from a comparative on-farm study in New Zealand. J Dairy Sci. 2019;102:2492-06.

42. Casoni D, Mirra A, Suter MR, Gutzwiller A, Spadavecchia C. Can disbudding of calves (one versus four weeks of age) induce chronic pain? Physiol Behav. 2019;199:47-55.

43. Caray D, de Boyerdes RA, Frouja S, Andanson S, Veissier I. Hot-iron disbudding: stress responses and behavior of 1- and 4-week-old calves receiving anti-inflammatory analgesia without or with sedation using xylazine. Livest Sci. 2015;179:22-8.

\section{Publisher's Note}

Springer Nature remains neutral with regard to jurisdictional claims in published maps and institutional affiliations.

Ready to submit your research? Choose BMC and benefit from:

- fast, convenient online submission

- thorough peer review by experienced researchers in your field

- rapid publication on acceptance

- support for research data, including large and complex data types

- gold Open Access which fosters wider collaboration and increased citations

- maximum visibility for your research: over $100 \mathrm{M}$ website views per year

At $\mathrm{BMC}$, research is always in progress.

Learn more biomedcentral.com/submissions 